〔126〕PVA の $8.7 \mu$ の結晶性バンドに関する知見

(1959 年 5 月 18 日受理)

今井清和*·浮田純二*・松本昌一*

\begin{abstract}
要旨 ポリビニルアルコール(PVA)の $8.7 \mu$ の結晶性バンドの虎属に関する知見を得るために， PVA モデル, PVA, PVA 共重合体の赤外線吸収スペクトルを $9 \mu$ 付近で測定した。その結果, (1) ヘプタ ントリオール-2,4,6 およびペンタンジオール-2,4 には PVA の結晶性バンドとよく類似した吸收が PVA とほとんど同じ位置に存在する。このバンドは希釈してもその强度を堿少しない。(2) PVA モデルのこのバ ンドは重水素化しても PVAの場合と同様に，吸収位置をはとんど変えない。(3) 重合度数十の PVAにも， 結晶性バンドは認められる。(4) PVA 浱厚水溶液扰よびそのゲル化物には, 結晶性バンドが観察されないこ とを認めた。これらの事実などから，結晶性バンドは結晶部分のトランス配固ジグザグ鎖の C-C 振動と分子 内水素結合した C-O 振動の両者が結合したものであろうと推論した。また PVA $9 \mu$ の付近にみられるその 他のバンドの归属についても考察した。
\end{abstract}

\section{1. 緒言}

PVAの赤外線吸收スペクトル (IR) で羿められる 8.7 $\mu, 1141 \sim 1146 \mathrm{~cm}^{-1}$ の吸収が強い2 色性を示すことは Elliot ら ${ }^{1)}$ が最初に指摘した。その後、これがいわゆる 結晶性バンド(crystallization-sensitive band) であるこ

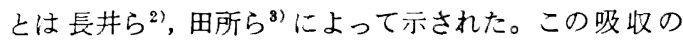
帰属を決的ることは興味ある問題であり，これ沉ついて は Elliot $5^{11}$, 西野 $5^{4}$, 長井 $5^{5)}$, 田所 $5^{6)}$, Krimm $ら^{71}$, $\mathrm{Haas}^{8)}$ の報告がある。田所ら ${ }^{6)}$ は主に二重配向した PVA および重水素化 PVA の偏光 IR から,このパン ドの双極子モーメントの方向は炭素ジグザグ鎖の面にほ ほ平行であり，またこのバンドは重水素化によって約 7 $\mathrm{cm}^{-1}$ 短波長側に移ることなどを明らかにした。同氏ら はこれらの事実から，この吸収帯は結晶領域中のトラン ス配置ジグザグ鎖の C-C 振動に主として基くものであ ろらと考えた。最近, 長井ら ${ }^{5 b)}$ はペンタンジオールー2, 4 の立体異性体の分離に成功し，その IR から結晶性バ ンドの帰属に関して有用な知識を得つつある。

箨者らはこの結晶性パンドの㷌属に関する知識を得る た如に, PVA モデル，PVA およびその共重合体のIR を測定した。得られた実駼結果とこのバンドの帰属に対 する筆者らの見解を述へておこう。筆者らの見解が正し いかどうかはさらに多くの実験と考察が必要であろう が，筆者らの得た害験結果はPVAの研究に少なくとも 役立つものと思い，発表するわけである。

\section{2. 实験方法}

PVA モデルとして用いたへプタントリオール $-2,4,6$ およびペンタンジオールー2, 4 は前報9に用いたものと同 一である。2-メチルーベンタンジオール-2,4,ペンタノー ルー3 およびペンタンジオール1, 6 はいずれも市販品を蒝 留で精製して用いた。溶剤の四塩化炭素, クロロホルム

\footnotetext{
* 倉数レイヨン株式会社研究所(倉敫市酒津)
}

は精製して使用した。PVA および共重合体の IR は厚 さ約 $5 \mu$ の皮膜について測定した。皮膜は水溶液から， 常温で製膜した。IR の測定は Perkin-Elmer 112 型に よった。プリズムは岩塩であり，溶液の測定に用いたセ ルの厚さは $0.5 \mathrm{~mm}$ であった。

\section{3. 実験結果ならびに考察}

\section{1 結晶性バンドの帰属}

ヘプタントリオール $2,4,6$ およびペンタンジオールー 2,4 の $9 \mu$ 付近の IR をPVA のそ机と比較して第 1 図 に示した。なおこれら PVA モデルの岩塩全領域の IR は別の報告9)に示した。トリオールおよびジオールにみ られる $1156 \mathrm{~cm}^{-1}$ の吸収位置と形は PVA の $1144 \mathrm{~cm}^{-1}$ の結晶性バンドのそれとよく類似している。また PVA の結晶性バンドの波数は重水素化によってほとんど変ら な( ${ }^{6,7)}$ が, PVA モデルの場合も第 1 図にみられるよう に重水素化によって波数をほとんど変えていない。この 点でもPVA モデルとPVAの両者はよく似ている。

他方, PVA の重合度を数十程度まで下げても, 第 2 図 にみられるように PVA の結晶性バンドは十分な強さで 存在している。しかも実験籁囲の低重合度 PVAの結晶 性パンドの強度は高重合度 PVAのそれ(実験点の図示 は省いた) 上りむしろ大きい。図の $D_{8.7}, D_{9.1}$ はそれぞ れ 8.7, 9.1 の吸収ピークのベースライン法で求めた 吸光度である。また図の重合度 60 以下の試料は $60^{\circ} \mathrm{C}$ で酶酸ビニル $4 \%$ ーエタノール $96 \%$ (いずれも重量)の溶 液重合で得た重合率 $70 \%$ の試料をポリ酢酸ビニルにつ いて分別し，ついでこれをケン化して得たものである。 この IR は厚さ約 $10 \mu$ のポリエチレン皮膜上に PVAを 約 $5 \mu$ に製膜し，この膜をはく離しないで，そのままポ リエチレンとともに測定したものである。薄膜ポリエチ ヘンはこの領域にほとんど吸収を示さないので，その存 在は無視した。なお長井ら ${ }^{\text {bb) }}$ は重合度 10 たらずの PVA オリゴマーにも結晶性パント゚の存在を認めている。 


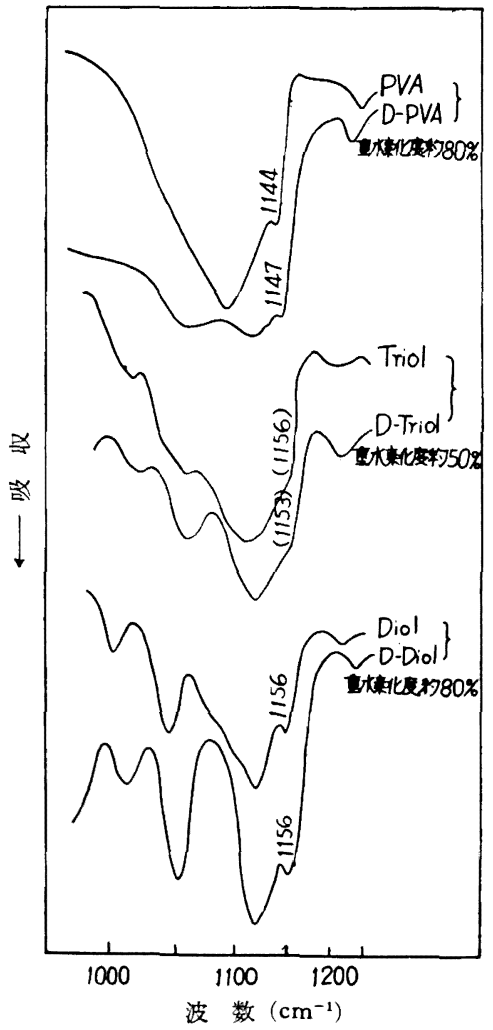

第 1 図 PVA，ヘプタントリナール $-2,4,6$ ，ペンタ ンジオール $-2,4$ およびこれら重水素化合物の IR

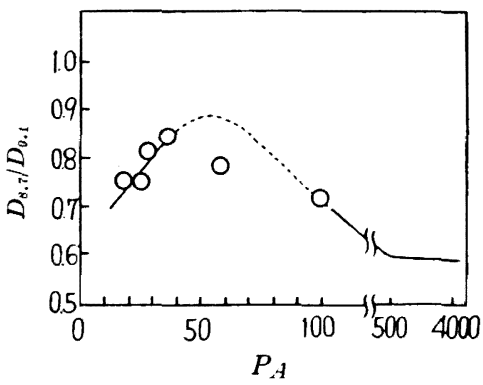

第 2 図 PVAの $D_{8.7} / D_{9.1}$ と重合度

したがって第 1,2 図より PVA モデルの $1156 \mathrm{~cm}^{-1}$ の 吸収は PVA の結晶性バンドと同種のものであると筆者 らは考える。PVA の結晶性パンドの䚻属を考えるため こ，PVA モデルの該バンドの㷌属をまず検討しよう。 PVA モデルの該吸収は液体で測定すると shoulder 程 度にすぎない(第1図)。しかしこれをクロロホルムない し四塩化炭素で希釈して測定すると，第 3,4 図のように 該吸收ははっきりしたピークになる。それゆえ,このバ ンドはモデル化合物の会合状態に特有なものではなく,

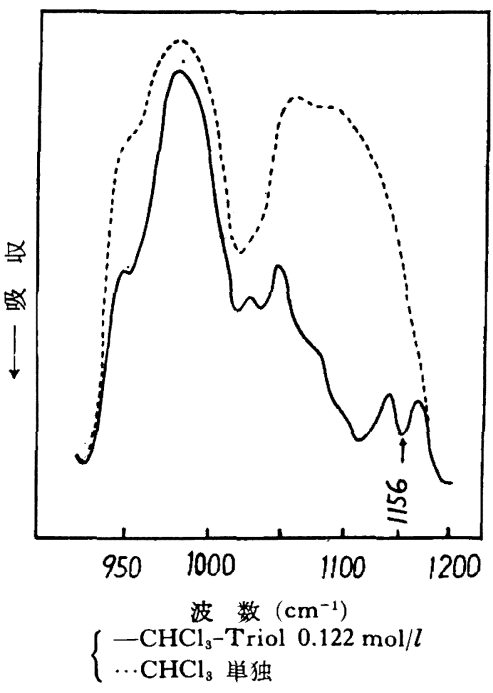

第3図クロロホルム中のヘプタントリ オール $-2,4,6$ の IR

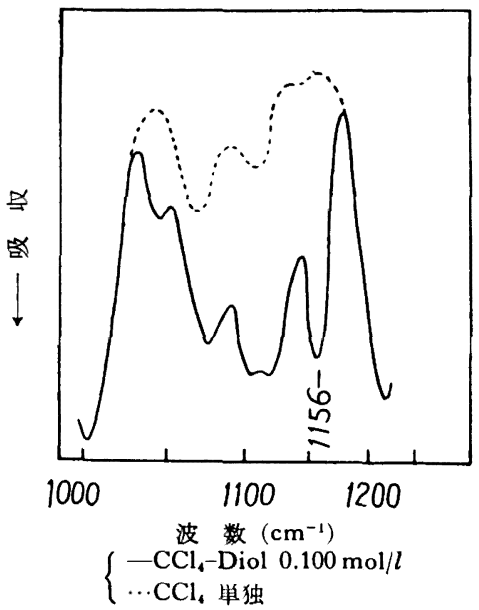

第 4 図四塩化炭素中のペンタンジ オール $-2,4$ の IR

遊離状態に特有なものと考えられる。試みにトリオール あるいはジオールの該吸収の $D / c(D$ は吸収度, $c$ は濃 度）を評価して第 5 図に示した。図にみられるようにこ の $D / c$ は $0.12 \sim 0.03 \mathrm{~mol} / l$ の測定範囲内では, ほほ一定 とみなされる。先に報告" ${ }^{9}$ したよ5にトリオールあるい はジオールは分子内水素結合を有しているが, この結合 量は実験濃度範囲では，同様に濃度によらず一定とみな された。この事実と第 5 図より，PVA モデルの該バン ドは分子内水素結合と関係があるように考えられる。

この点をさらに確かめるために 2-メチルーペンタンジ オール $-2,4$; ペンタノール -3 およびペンタンジオールー 


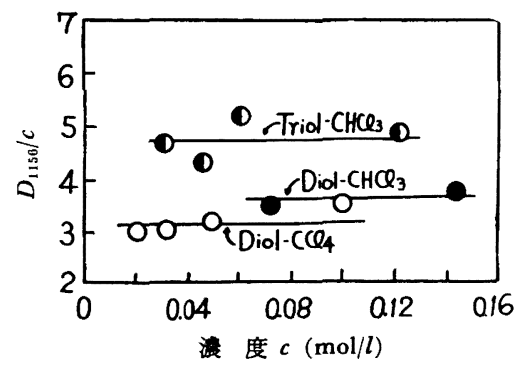

第 5 図四塩化炭素あるいはクロロホルム中の ヘプタントリオール $-2,4,6$ および ペンタン ジオール 2,4 の $D / c$ と $c$ の関倸

1,5 の IR を測定した。それはもし PVA モデルの該バ ンドが分子内水素結合に関係したものであるならば，2メチルーペンタンジオール $-2,4$ にはその類似吸収が認め られようが, 後 2 者にはそのような吸収は存在しないは ずだと考えたからである。このIRを第 6 図に示した。 測定結果は予想とよく一致して,2-メチルーペンタンジオ ール-2,4 には, PVA モデルの $1156 \mathrm{~cm}^{-1}$ によく類似し

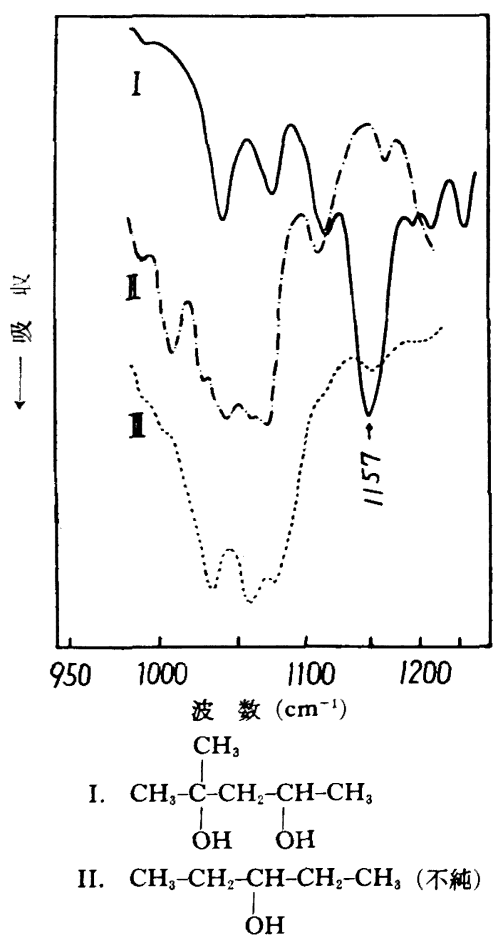

III. $\mathrm{CH}_{2}-\mathrm{CH}_{2}-\mathrm{CH}_{2}-\mathrm{CH}_{2}-\mathrm{CH}_{2}$ ${ }_{\mathrm{OH}} \quad \mathrm{OH}$

第 6 図 2-メチルーペンタンジオール $-2,4$, ペン タノールー3 およびペンタンジオールー 1,5 の $\mathrm{IR}$, 液体
た吸収を $1157 \mathrm{~cm}^{-1}$ に認めたが, 後 2 者にはそのような 吸収は存在しなかった。なお2-メチルーペンタンジオー ル-2, 4 は第 3 級アルコールの $\mathrm{OH}$ を含むが, この 1157 $\mathrm{cm}^{-1}$ の吸収は一部，第 3 級アルコールのレ(C-O) に基 くかも知れない。しかし，この吸収はこの付近で格段に 強、吸収であり，これを第 3 級アルコールのレ(C-O) の みだとすると第 2 級アルコールのそれをいずれの吸収と 結びつけて良いかかからなくなる。この第 2 級アルコー ルのン (C-O) の吸収が第 3 級アルコールのそれに比して 格段に弱いことはありえないようである ${ }^{10)}$ 。

さて, PVAの $9 \mu$ 付近に吸収を与える振動としては, 一般にっ $(\mathrm{C}-\mathrm{O})^{11)}$ と引き伸ばされたジグザグ鎖のっ(CC) $)^{12)}$ の 2 者がまず考えられよう。しかし Stuart ら ${ }^{10)}$ が いったようにこの領域の吸収は上記両者が結合した 几(C-C+C-O) を考えるのがより一般的であろう。もっ とも両者の寄与いかんによっては，その振動がより純粋 なっ(C-C) あるいは られよう。この意味で $8.7 \mu$ の㷌属としてょ $(\mathrm{C}-\mathrm{C}+\mathrm{C}-\mathrm{O})$, レ(C-C) およびょ(C-O)の3者があげられる。しかし， このなかで純粋なっ (C-O) は考えにくいと思う。それは 田所ら ${ }^{6}$ も考慮し，Krimm ら”もいっていることである が, 重水素化によってそのバンドの位置がほとんど動か ないことからも明らかであらう。また島内，水島 ${ }^{18)}$ はラ マン線の測定から，炭素数 16 のセタンは液体で炭素数 4〜12 のジグザグ鎖をもつことを示している。もし結晶 性パンドが純粋なっ(C-C) であれば，PVA 水溶液，特 にそれがゲル化したものでは，結晶性バンドが認められ て良いはずである。しかし第7図に示したように実測の 結果はそうでなく, 結晶性バンドの位置に吸収はほとん ど認められなかった。それゆえ上記 3 者の5ち，っ(C-C $+\mathrm{C}-\mathrm{O})$ が最も妥当だと考える*。しかも筆者らは PVA

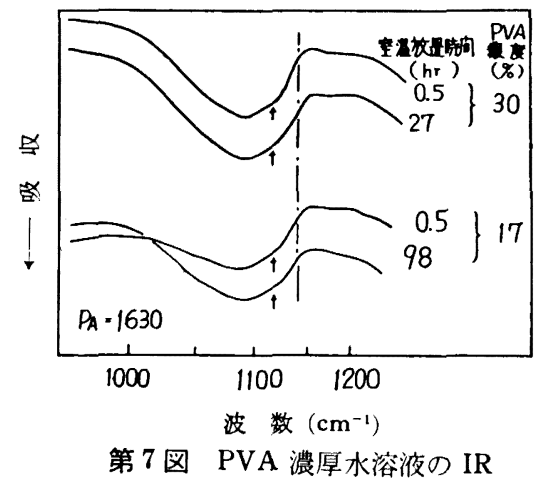

* 脱稿後 C.Y. Liang, F.G. Pearson [ $J$. Polym. Sci., 35, 303(1959)] がこの結晶性バンドはおそらく OCC の対称骨格 振動に基くであろらと考察していることを知った。すなわち PVA の場合, C-C 振動と C-O 振動を区別するのは不当だと考 えている。この点, 筆者らの推論と一致している。 
の結晶性バンドと PVA モデルの $1156 \mathrm{~cm}^{-1}$ のバンドと は同種のものであり，㷌属は両者一貫してなされね枯な らないと考えるから，レ(C-C+C-O) の C-O は分子内 水素結合を形成していることになる。すなわち PVA の 結晶性バンドは結晶領域のトランス配置ジグザグ鎖の C-C 振動と分子内水素結合した C-O 振動とが結合した 振動に基くものと推論する。な扔このよらに考えても, このバンドが垂直 2 色性を示し, またその双極子モーメ ントがジグザグ鎖面にほぼ平行である事実(6) と矛盾しな い。

上述の㷌属は PVA の結晶領域内にも分子内水素結合 の存在することを要求する。これは PVA の結晶構造の X線図的研究では, 従来考虑されなかったことである。 しかし，この考え方は必ずしも不当ではないと考える。 すなわち Bunn ${ }^{14)}$ は, X镍図的研究で PVAの $\mathrm{OH} の$ 立体配置は結晶領域でも不規則だとした。結晶部分の

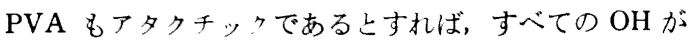
例外なく分子間水素結台を形成していることは考えにく い。結晶内に必ず遊離 $\mathrm{OH}$ が存在するであろ5。しかし この遊離 $\mathrm{OH}$ はその状態上りも, 分子内水素結合を形成 している方がエネルギー的により有利であろう。また PVA モデルの分子内水素結合は意外強固であり, 石 炭酸(プロント供与体)あるい流へキサメチレンテトラミ ン(プロトン受容体)を添加しても，その結合は容易には 破壊される様子が見受けられなかった を考えると, 結晶領域内に分子内水素結合の存在寸る可 能性は十分あるように考える。

またPVAの結晶性バンドの強度は母体ポリ酢酸ビニ ルの重合温度で変り, 重合温度が低下するとこの吸収带 の強度は増す ${ }^{15)}$ が，計数管による干涉曲線の形およびそ の積分强度は重合温度 $\left(0 \sim 160^{\circ} \mathrm{C}\right)$ 上無関倸にほぼ一定に

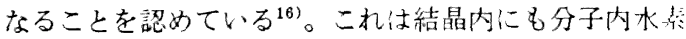
結合が存在するとし， $8.7 \mu$ に関する㷌属を上述のように し C-C $+\mathrm{C}-\mathrm{O})$ とすれば，次の上うに解秋できる。すなわ ち, X線干涉曲線が試料の重合条件で変らないのは, $\mathrm{OH}$ の立体特異性が PVAの結晶化に無関係であるという Bunn ${ }^{14)}$ の考え方が基本的に正しいか，あるいはその他 に起因しているのであろう。この原因がもし前者にあ り, PVAの結晶化度が重合温度に上って事実上変らな いてしても，PVAの立体特異性は重合温度で変るから， 結晶領域において分子内水素結合を形成している $\mathrm{OH}$ 基 量の全 $\mathrm{OH}$ 基量に対する比は変わるであろら。この比が 变れば, 結晶性バンドの強度は上述の㷌属から, 当然変 化しなければならないことになる。

PVA の分子内水素結合の $\mathrm{OH} \cdots \mathrm{O}$ 距離は $2.5 \AA$ にな るはずである。この距雕は通常の水素結合のそれに比し て小さい。しかし，これは不当に小さい值ではない。た とえば Kuhn" ${ }^{17)}$ はシスーシクロへキサンジオール-2, 4 で
分子内水素結合の存在を認めている。この化合物には第 8 図のような反転異性体が考えられるが, 分子内水素結

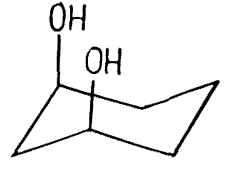

(I)

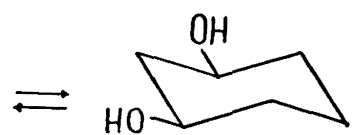

(II)
第 8 図 シスーシクロヘキサンジオールー 2,4 の分子構造

合の存在浪の (II) の構造で法考えられない。それゆえ (I)の構造が分子内水素結合を有していることになる。 この $\mathrm{OH} \cdots \mathrm{O}$ 距離は明らかに $2.5 \AA$ である。したがって， PVA の場合にも, $\mathrm{OH} \cdots \mathrm{O}$ 距離が $2.5 \AA$ の分子内水素結 合が十分ありらると考える ${ }^{18)}$ 。

\section{$3.29 \mu$ 付近のその他のバンドの帰属}

次に PVAの $9 \mu$ 付近にみられるその他のバンド, す なわち結晶性バンド以外の吸收带の㷌属について検討し よう。そうすることは $8.7 \mu$ の㷌属を考える上にも参考 になろら。

PVA の $9 \mu$ 付近の吸収としては $9.1 \mu, 1090 \sim 1100$ $\mathrm{cm}^{-1}$ のピーク以外に, このバンドの長波長側の非対称 部分を形成している $1040 \mathrm{~cm}^{-1}$ 付近の吸収 ${ }^{19)}$ と $9.1 \mu$ と $8.7 \mu$ の両吸収の間に, ときに shoulder として認められ る $1120 \mathrm{~cm}^{-1}$ 付近の吸收 ${ }^{20)}$ がある。

$1090 \mathrm{~cm}^{-1}$ のパンドが主としてっ(C-O) に基くであ ろうことは従来異論がない。液体第 2 級アルコールの $\nu(\mathrm{C}-\mathrm{O})$ は $1100 \mathrm{~cm}^{-1}$ 付近に生するる ${ }^{10)}$ から, PVAの 1090 $\mathrm{cm}^{-1}$ の吸收は主に水素結合した $2(\mathrm{C}-\mathrm{O})$ と考えて良い であろう。水素結合には分子内, 分子間ならびに吸着水 とのものが考えられるが,これらのいずれもが $1090 \mathrm{~cm}^{-1}$ 付近に集まり，この領域で最も強い吸収を与えているも のと考えられる。

$1040 \mathrm{~cm}^{-1}$ 付近の吸收は非晶部分の何らかの振動が主 に寄与しているよらである。それは PVA のこの部分の 吸收甜低温重合物よりも高温重合物の方がより大き く ${ }^{19)}$ ，しかも熱処理によってその強度は減ずる傾向がす る(第 10 図参照)こと，また第 9 図に示したビニルアル コールイソプロペニルアルコール共重合体についても同 様な傾向が認められることから考えられる。なお遊崔の C-O 振動が会合状態のそれに比して長波長側にずれる ことが低分子のアルコールで知られている(10) からら, 9.1 $\mu$ の吸収が水素結合した $\nu(C-O)$ であるのに対し，これ は遊離の $(\mathrm{C}-\mathrm{O})$ であるかも知れない。

$1120 \mathrm{~cm}^{-1}$ 付近の吸収は PVA の分子構造の乱れが少 なく, 結晶性の良いと考えられる PVA では認めにくい が, 結晶性の少ると考えられる PVA では, shoulder と して観察される。しかも、このバンドの強度は熱処理に 


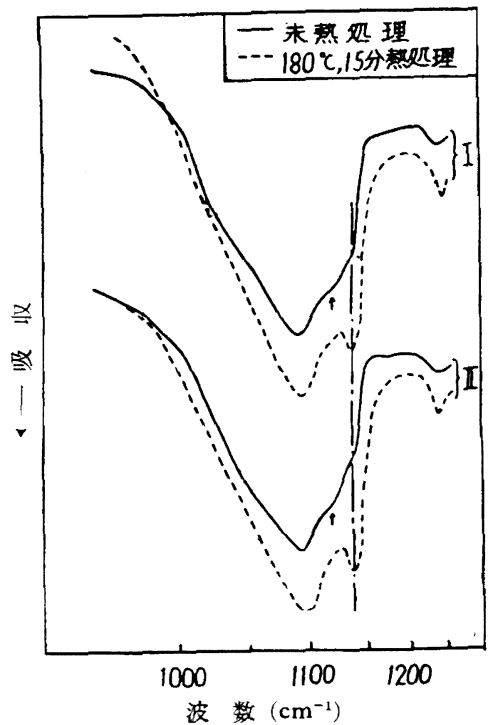

共重合体の重合温度: $60^{\circ} \mathrm{C}$

共重合体中のイソプロペニルアルコール (モル \%) I 2.9

II 4.3

第 9 図ビニルアルコールーイソプロペニルアル コール共重合体のIR, 熱処理の影響

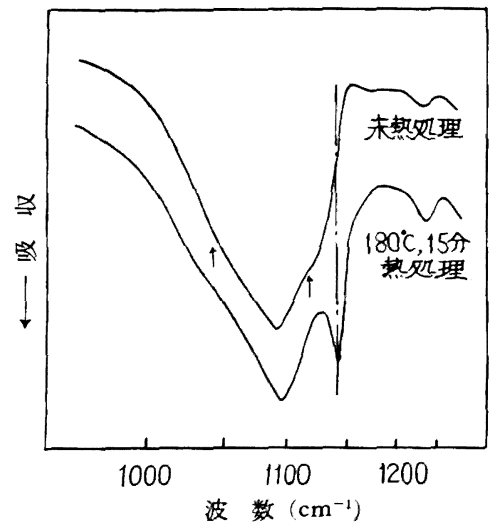

重合温度 $160^{\circ} \mathrm{C}$, 重合索 $10.5 \%$ $P_{A}=1420$ (大柳氏合成, 番号 53)

第 10 図高温重合 PVAのIR

よって減少するようである20)。この実験例を第 10 図に 示した。それゆえこの吸収は非晶領域に起因しているよ うである。筆者らはこのバンドは $8.7 \mu$ の結晶性バンド
に対応した非晶領域の いる。このように考えれば第 7 図, PVA 水溶液の IR で認められる $1120 \mathrm{~cm}^{-1}$ の吸収の存在も理解できよう。

付 記: 本研究の大部分は高分子学会年会 (1957.6. 於 東京)で発表した。終りにへプタントリオールー2,4,6 をいただ いた三宅泰治氏, また発表の機会を与えられた会社当局に感謝 します。

\section{文献}

1) A. Elliot, E. J. Ambrose and R.B. Temple: J. Chem. Phys., 16, 877 (1948)

2) 長井, 美馬, 栗林, 相根: 高化, 12, 199 (1955)

3) 田所, 関, 仁田 : Bull. Chem. Soc. Japan, 28, 559 (1955)

4) 西野, 浮田, 小南: 工化, 58, 159 (1955)

5) (a) 長井, 栗林: 高化, 12, 322, 368(1955); (b) 長 井, 栗林, 白木, 浮田：高分子討論会発表 (1958. 10. 於大阪)；J. Polym. Sci., 35, 295(1959)

6) 田所, 関, 仁田: J. Polym.Sci., 22, 563(1956); 田 所, 香西, 関, 仁田: ibid., 26, 379(1957); 田所, 関, 仁田, 山寺: ibid., 28, 244 (1958)

7) S. Krimm, C.Y. Liang and G.B.B.M. Sutherland : J. Polym. Sci., 22, 227 (1956)

8) H.C. Hass: J. Polym. Sci., 26, 391 (1957)

9) 松本, 今井: 高化, 15, 160 (1958)

10) A.V. Stuart and G.B.B.M. Sutherland: J. Chem. Phys., 29, 559 (1956)

11) たとえば L. J. Bellamy： “The Infrared Spectra of Complex Molecules" 参照

12) 水島, 島内: J. Am. Chem. Soc., 71, $1320(1949)$; 島内, 水島：J. Chem. Phys., 17, 1102(1949); S. Krimm, C.Y. Liang and G.B.B.M. Sutherland: J. Chem. Phys., 25, 549(1956); J.R. Nielsen and A.H. Woollett: J. Chem. Phys., 26, 1391 (1957)

13)帛内, 水岛：Sci. Pap. Inst. Phys. Chem. Res. Tokyo., 40, 467 (1943)

14) C.W. Bunn: Nature, 161, 929 (1948)

15) 今井, 前田, 浮田, 松本：高化, 16, 446 (1959)

16）筆者ら：末発卡，当所の望月隆仁氏に测定を依頼 した。

17) L.P. Kuhn: J. Am. Chem. Soc., 74, 2492 (1952)

18）関, 千原, 鉿木：現代化学 “水素結合”岩波, 39 40 (1956) によると現在知られている最も短い水素

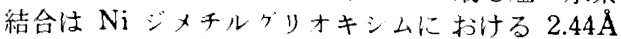

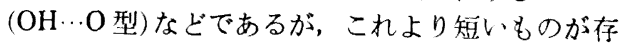
在しないといら証拠はない由である。

19) 長井, 相根：工化, 59, 794 (1956)

20）田所：桜田編“ポリビニルアルコール”257(1956) 


\title{
Information on the Crystallization-Sensitive Band at $8.7 \mu$ of Polyvinyl Alcohol
}

\author{
By Kiyokazu Imai*, Junji Ukida* and Masakazu Matsumoto*
}

The infrared spectra of PVA model, PVA and copolymer of vinyl alcohol have been investigated at about $9 \mu$ region to obtain some informations on the crystallization-sensitive band at $8.7 \mu$ of PVA. Then, the following facts were observed: (1) in PVA model, namely heptanetriol-2,4,6 and pentanediol-2,4, the analogous bands to the crystallization-sensitive band of PVA appeared at nearly the same position, (2) the analogous band locations did not almost shift on deutration, just like PVA (3) the existence of crystallization-sensitive band even for the PVA whose polymerization degree was several tens, (4) no observations of crystallization-sensitive band for concentrated aqueous solutions of PVA and their gels. From such observations and data by another authors, it may be infered that the crystallization band will be associated with the coupling mode between $\mathrm{C}-\mathrm{C}$ vibration of trans conformation and $\mathrm{C}-\mathrm{O}$ vibration in that which formed intramolecular hydrogen bond in the crystalline region. It was also discussed about the assignment for another bands at $9 \mu$ region of PVA.

* Research Lab., Kurashiki Rayon Co. Ltd. (Kurashiki, Okayama) 